\title{
A multivariate analysis of risk factors influencing the cesarean section rate in two university hospitals in Leiden (the Netherlands) and Bandung (Indonesia)
}

Firman F. Wirakusumah", R.Brand ${ }^{\dagger}$, J.Bennebroek Gravenhorst $^{\ddagger}$

\begin{abstract}
Abstrak
Telah dilakukan penelitian tentang faktor-faktor risiko dan hubungan faktor-faktor tersebut dalam proses pengambilan keputusan melakukan tindakan seksio sesarea. Metode yang dipakai adalah analisis multivariat. Dilakukan pula penilaian besarnya risiko yang mempengaruhi proses pengambilan keputusan untuk operasi tersebut. Penelitian ini bertujuan melakukan identifikasi faktor-faktor yang dapat dipakai dalam menduga hasil persalinan di rumah sakit yang diwakili, satu rumah sakit pendidikan di suatu negara berkembang dan yang lainnya dari suatu rumah sakit pendidikan negara maju. Bahan penelitian didapat dari catatan medik di dua rumah sakit, yaitu Rumah Sakit Pendidikan Leiden, Nederland, dan Rumah Sakit Pendidikan Dr. Hasan Sadikin Bandung, Indonesia. Metodologi adalah suatu penelitian kohor berbasis rumah sakit selama 10 tahun dengan perhatian khusus pada hasil persalinan dengan seksio sesarea. Di Rumah Sakit Pendidikan Leiden didapatkan faktor-faktor risiko yang jelas berpengaruh pada kemungkinan dilakukannya seksio sesarea adalah: umur tua, primigravida, sikatriks uterus, komplikasi antenatal primer, kehamilan ganda, letak sungsang dan kelainan letak lainnya. DiBandung faktor-faktor tersebut di atas juga jelas berpengaruh pada tindakan seksio sesarea, kecualikehamilan ganda. Ada beberapa faktor lain yang berperan di Bandung yaitu lama persalinan, asal dari luar kota, jarang memeriksakan kehamilan dan berpendidikan rendah.
\end{abstract}

\begin{abstract}
The relationship between a number of factors that play a role in the decision-making process resulting in a cesarean section and the risk of undergoing a cesarean section is analysed by multivariate analysis methods. Subsequently the degree to which these risk factors influenced the decision making process is evaluated. This study was designed to identify factors that can be used to predict both fetal and maternal outcome in hospitals in developed and developing countries. The material for this study was obtained from the records of two hospitals: the university hospital of the Leiden Medical Faculty representing a hospital from a developed country and the Hasan Sadikin Hospital of the Padjadjaran Faculty of Medicine, Bandung, situated in a developing country. The outcome of Cesarean section in a hospital-based cohort covering a 10-year period was evaluated. In Leiden, the following risk factors were significantly associated with the probability of a cesarean section: advance age; primigravida; the presence of a uterine scar; primary antenatal complications; multiple pregnancies; breech position and other unusual presentations. In Bandung, the same risk factors were statistically significant except that multiple pregnancy did not play a role. Furthermore the duration of labor; coming from a rural area, few prenatal visits, and low educational level played and important role in Bandung.
\end{abstract}

Keywords: Cesarean section; risk factor; multivariate analysis.

\section{INTRODUCTION}

During the 10 year period between 1981 and 1991 the cesarean section rate in the Leiden university hospital (AZL) in the Netherlands appears to be identical

\footnotetext{
"Department of Obstetrics and Gynecology Faculty of Medicine, Padjadjaran University, Bandung, Indonesia

+ Department of Medical Statistics, Faculty of Medicine, University of Leiden, Leiden, The Netherlands

${ }^{\ddagger}$ Faculty of Medicine, University of Leiden, Leiden, The Netherlands
}

$(9,1 \%)$ to that in the university hospital of the Padjadjaran university in Bandung (HSHB), Indonesia. The indications to perform a cesarean delivery were however in some aspects different.

The objective of this study is to analyse the influence of a number of possible risk factors, alone or in association, on the decision to perforn a cesarean section in two different obstetrical care systems. For this purpose the computerised data of all the abdominal births that took place during the period January 1 th 1981 and December 31th 1990 were studied. 


\section{METHODS}

The probability of a cesarean section is estimated applying multivariate logistic regression models to all maternity casies obtained from the hospital records of both hospitals under study. The choice of risk factors was based on availability in the hospital records and on current literature, in advance and without investigating the data themselves.

To enable a meaningful interpretation of the various regression coefficients (in terms of odds ratios or relative risks), the risk factors were grouped into 3 (Leiden) or 4 (Bandung) time categories: (1) maternal characteristics, (2) prepregnancy, (3) pregnancy, and (4) prenatal visits (as a separate category in Bandung only). To estimate the multivariate effect of any risk factor on the probability of a cesarean section, adjustments were made only for risk factors occurring in the same or earlier time category: the purpose of this is avoiding to adjust for a covariate which might simply be the consequence of another risk factor occurring earlier in time, thus rendering the interpretation as a relative risk impossible. The following risk factors were used in the logistic models as suggested by Brand: ${ }^{1,2}$ (1) maternal age, residence, formal education; (2) parity, uterine scar; (3) primary antenatal complications, multiple pregnancies, rupture of the membranes, duration of labor, type of labor, fetal presentation; and (4) prenatal visits.

Summarizing the approach sketched above, the following logistic models were fit to the data in order to obtain multivariate relationships between these risk factors and the outcome "cesarean section" in Leiden and Bandung respectively :

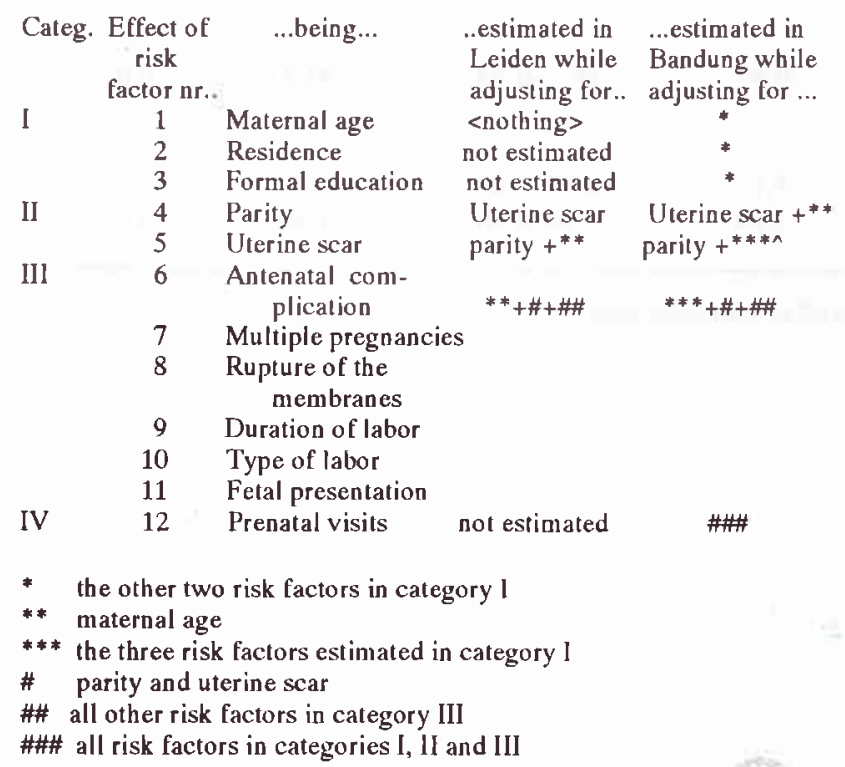

The association between a risk factor and the outcome "probability of cesarean section" is expressed as an (un)adjusted odds ratio (OR). The Crude Odds Ratio (cOR) is the ratio between the odds in two categories without adjusting for any other factors; the Adjusted Odds Ratio (OR) measures the impact of a 1- unit-increase in the corresponding risk factor on the odds of cesarean section adjusted for the other risk factors, i.e. comparing pregnancies identical on all other risk factor considered by the model.

Although the Likelihood Ration Test statistic is usually the preferred one to test for a significant association in the context of logistic regression, the extremely large number of observations led us to use the (approximate) Wald test for significance testing as well computation of $95 \%$ confidence intervals, both in view of the reduced computation time involved and the fact that the Wald test is nearly identical to the LR test in these large data sets. For data storage and descriptive analyses we used SPSS; logistic modelling was performed using BMDP (LR).

\section{RESULTS AND DISCUSSION}

The study encompassed 13,278 women in Leiden and 29,740 women in Bandung who gave birth between January 1, 1981 and December 31, 1990. In total 1,211 cesarean sections were performed in Leiden and 2,704 in Bandung.

\section{Maternal age}

The maternal age factor was assessed in a logistic regression equation using the age categories listed in Tables 1 and 2. Marieskind ${ }^{3}$ suggested that the management of labor is different for older women than that for younger women. Some investigators have reported that the probability of a cesarean delivery is higher for older women. ${ }^{4-9}$ The present study also shows that maternal age is associated with the probability of a cesarean section. The trend was asystematically increasing probability of cesarean section with advancing age in Leiden; the probability of cesarean delivery, as given by the adjusted odds ratio for age group 20-30 y rs was OR = 1.80; age group 30-35 yrs, adjusted $\mathrm{OR}=2.90$; and age $>35$ yrs, adjusted $\mathrm{OR}=$ 3.28. For Bandung the adjusted OR's were: 1.47, 2.01 and 1.91, respectively. It appears that both in Bandung and in Leiden the risk for a cesarean delivery is higher for women over 30 years. 
Table 1. Crude and adjusted odds ratio for cesarean risk categories; AZL, 1981-1990

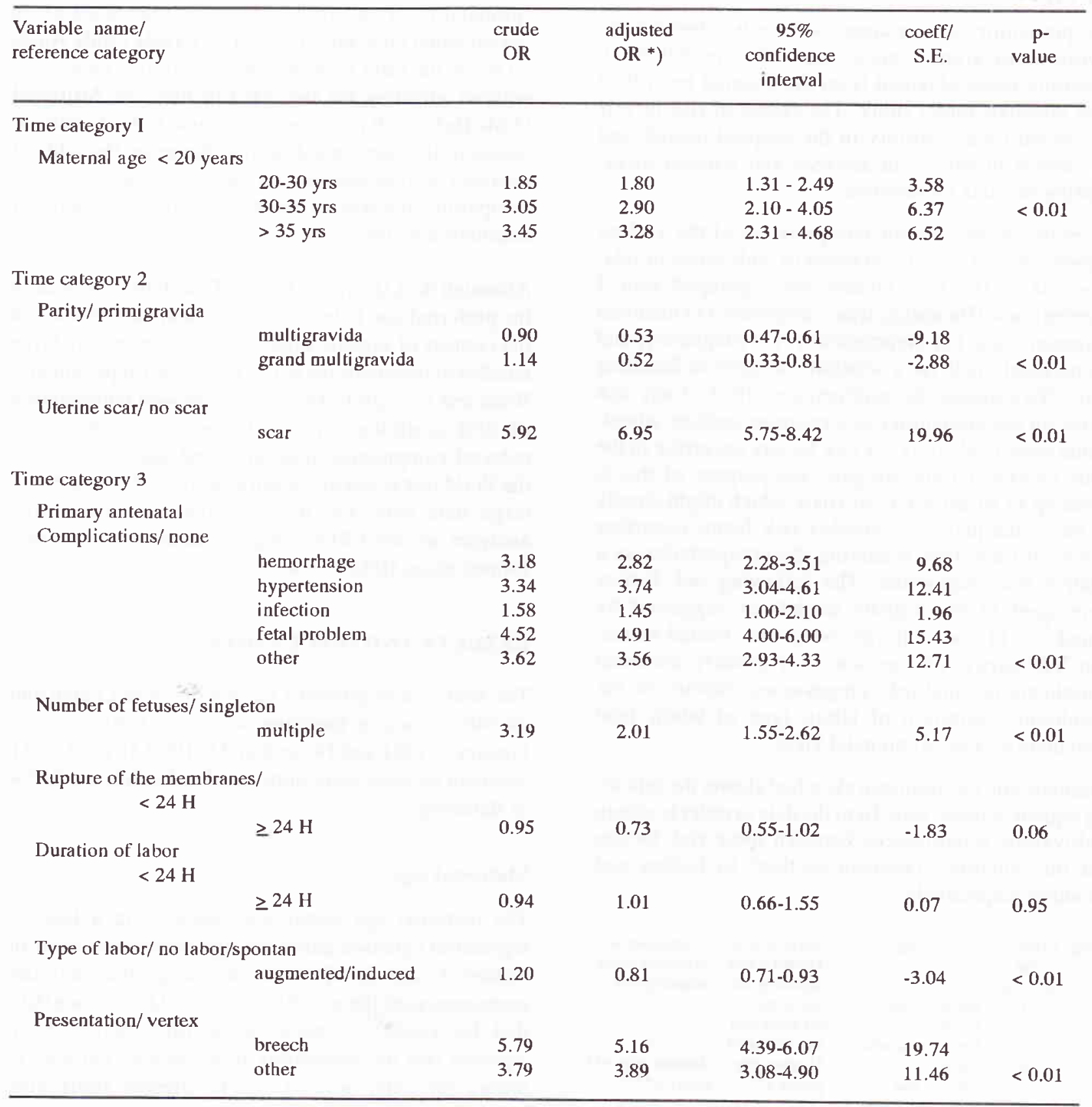

*) adjusted for all variables in the same and prior time categories, as well-as calender year. 
Table 2. Crude and adjusted odds ratio for cesarean risk categories; HSHB, 1981-1990

\begin{tabular}{|c|c|c|c|c|c|c|}
\hline $\begin{array}{l}\text { Variable name/ } \\
\text { reference category }\end{array}$ & & $\begin{array}{l}\text { crude } \\
\text { OR }\end{array}$ & $\begin{array}{l}\text { adjusted } \\
\left.\mathrm{OR}^{*}\right)\end{array}$ & $\begin{array}{c}95 \% \\
\text { confidence } \\
\text { interval }\end{array}$ & $\begin{array}{l}\text { coeff/ } \\
\text { S.E. }\end{array}$ & $\begin{array}{c}\text { p- } \\
\text { value }\end{array}$ \\
\hline \multicolumn{7}{|c|}{ Time category 1} \\
\hline \multicolumn{7}{|c|}{ Maternal age $<20$ years } \\
\hline & $20-30 \mathrm{yrs}$ & 1.26 & 1.47 & $1.28-1.69$ & 5.65 & \\
\hline & $30-35$ yrs & 1.95 & 2.01 & $1.75-2.30$ & 9.57 & $<0.01$ \\
\hline & $>35 \mathrm{yrs}$ & 2.11 & 1.91 & $1.63-2.23$ & 7.38 & \\
\hline \multicolumn{7}{|c|}{ Residence/ urban } \\
\hline & rural & 1.93 & 1.67 & $1.55-1.81$ & 12.23 & \\
\hline \multicolumn{7}{|l|}{ Education/ low } \\
\hline & high & 1.83 & 0.64 & $0.59-0.97$ & -10.46 & \\
\hline \multicolumn{7}{|c|}{ Time category 2} \\
\hline \multicolumn{7}{|c|}{ Parity/ primigravida } \\
\hline & multigravida & 1.25 & 0.75 & $0.69-0.83$ & -5.45 & \\
\hline & grand multigravida & 1.55 & 0.59 & $0.51-0.71$ & -5.90 & $<0.01$ \\
\hline Uterine scar/ no scar & scar & 10.41 & 12.32 & $10.15-14.76$ & 25.55 & $<0.01$ \\
\hline
\end{tabular}

Time category 3

Primary antenatal

Complications/ none

$\begin{array}{lr}\text { hemorrhage } & 44.23 \\ \text { hypertension } & 3.2 \\ \text { infection } & 7.72 \\ \text { fetal problem } & 5.99 \\ \text { other } & 10.25\end{array}$

48.10-61.97

53.32

3.21
7.72

3.59

$3.04-4.22$

13.58

5.99

7.43

$6.42-8.59$

23.45

10.25

8.80

$1.17-2.88$

8.29

$7.50-10.34$

22.84

Number of fetuses/singleton

multiple

0.63

$0.49-0.80$

$-3.19<0.01$

Rupture of the membranes/

$$
<24 \mathrm{H}
$$

Duration of labor/

$$
\geq 24 \mathrm{H}
$$

$$
<24 \mathrm{H}
$$$$
\geq 24 \mathrm{H}
$$

1.72

$1.29-2.30$

3.12

$<0.01$

Type of labor/ no labor/spontan

Presentation/ vertex

$\begin{array}{lrrccr}\text { augmented/induced } & 09 & .20 & 1.08-1.34 & 3.05 & <0.01 \\ \begin{array}{l}\text { breech } \\ \text { other }\end{array} & 2.35 & 2.71 & 1.28-3.04 & 12.90 & \\ & 17.08 & 25.25 & 20.97-30.36 & 34.04 & <0.01\end{array}$

Time category 4

Prenatal visits/ tew

$$
\text { many }
$$

0.46

0.87

0.79-0.98

$-1.92$

$<0.03$

*) adjusted for all variables in the same and prior time categories, as well as calender year 


\section{Residence}

Women from rural areas had a significantly higher risk for cesarean delivery in Bandung ( $p<0.01$; crude OR = 1.93; adjusted OR = 1.67) (Table 2$)$, in fact, women suffering from prolonged/ obstructed labor and antepartum hemorrhage often came from the countryside around Bandung and these two conditions were important indications for cesarean section. ${ }^{10}$

\section{Formal education}

The importance of formal education (and prenatal visits) in relation to matemity care in Bandung has been studied by means of trivariate analyses. We conclude that prenatal visits and formal education together may have reduced the antenatal complications preceding both vaginal delivery and cesarean section. ${ }^{10}$ Moreover, by using logistic regression analyses, we have demonstrated that the probability of a cesarean section for educated women is lower compared to women with less education, but of the same age and residency (adjusted for maternal age and residency: $\mathrm{OR}=0.64, \mathrm{p}<0.01$ ).

\section{Parity}

"Multiparity" was analyzed in category 2: The probability of a cesarean section for women in Leiden was higher for primigravida than for multigravida. This is illustrated by the adjusted OR's which were 0.53 and 0.52 for multigravida and grand multigravida, respectively (Table 1). For Bandung, the adjusted OR's were 0.75 and 0.59 , respectively (Table 2 ). Francome and Huntingford ${ }^{11}$ as well as Gleicher ${ }^{12}$ reported that the frequency of cesarean deliveries among primigravida was about three time that found for multiparous women. In contrast Hurst and Summey ${ }^{13}$ noted that parity had no effect on the cesarean birthrate.

\section{History of a previous cesarean delivery}

As expected, we found a high risk for women with a history of previous cesarean deliveries (women with a uterine scar). It has been claimed that a previous cesarean delivery increases the probability of a repeat cesarean delivery. ${ }^{14-17}$ The crude and adjusted OR's for women with a uterine scar were 5.92 and 6.95, respectively, in Leiden and 10.41 and 12.32 , respectively, in Bandung (Table 1,2). After correction for potential confounding factors, this factor is still associated with the decision to perform a cesarean section.
The results of the present analysis imply a high risk for the procedure (cesarean delivery) compared to that for women without a uterine scar. When the results for the two hospitals are compared, it is surprising that during the period studied the odds ratio was twice as high in Bandung as in Leiden. We hypothesize that this difference may be the result of differences in policy. In Leiden Cragin's dictum ${ }^{18}$ "once a cesarean, always a cesarean" does not apply, but in Bandung a primary repeat cesarean delivery was always performed in the case of a history of at least two previous cesarean births, almost always combined with tubal ligation. ${ }^{10}$

\section{Primary antenatal complications}

The presence of primary antenatal complications gave an increased risk of cesarean delivery in both hospitals (Table 1 and 2). Interestingly, hemorrhage represented an unacceptably high risk for cesarean section for women in Bandung ( $p<0.01$; crude OR = 44.23; adjusted OR = 54.67); in contrast this risk was relatively low in Leiden ( $p<0.01$; crude $O R=3.18$; adjusted OR $=2.82$ ). The marked difference in ratio's between the two hospitals was also demonstrated by the marked differences in the percentage of patients with antepartum hemorrhage as an indication for cesarean delivery, as shown by Wirakusumah. ${ }^{10}$

Both the high risk or a cesarean section found for the category hemorrhage of the antenatal complications and the high percentage of antepartum hemorrhages considered an indication for cesarean section in Bandung is probably caused by overdiagnosis. In Leiden an antenatal hemorrhage was only considered an indication for cesarean section if confirmed to be a placenta previa by ultrasound. In Bandung ultrasound was not possible in this period and hence overdiagnosis is likely to have occured.

\section{Number of fetuses}

We found a lower OR for women with multiple fetuses in Bandung than in Leiden. We may assume that there was a different pattern of multiple pregnancies in the two hospitals. In Leiden there were many multiple pregnancies, particularly triplets or more in the late years of the decade due to modern reproductive technology. Wirakusumah ${ }^{10}$ reported that the percentage of women with a multiple pregnancy who underwent a cesarean section increased markedly in Leiden. Of the 14 multiple pregnancies delivered by cesarean section in the period 1981-1983, only one was reported to be a triplet. In period 1988-1990 there were 17 cases of triplets and higher-order births among 59 multiple 
pregnancies. In contrast, in Bandung there was only one quadruplet out of 21 cases of multiple pregnancies delivered by cesarean by cesarean section during period 1981-1983. In the period 1988-1990 there were no cases of triplets or higher-order birth out of 17 cases of multiple pregnancies delivered by cesarean section. ${ }^{10}$ The introduction of ovulation stimulating drugs and the increased age of primigravida in developed countries explain these differences between the two populations. 19,20

\section{Rupture of the membranes}

A prolonged period between the moment of membrane rupture and the onset of labor did not affect the probability of a cesarean section significantly for women in either hospital.

\section{Duration of labor}

Duration of labor was not related to the probability of performing cesarean section in Leiden. However, in Bandung the relation was statistically significant $(p<0.01)$, although the influence of the duration of labor on the probability of a cesarean section was not extremely high (adjusted OR = 1.72) $($ Table 1,2).

\section{Type of labor}

The type of labor in relation to the probability of a cesarean section in the two hospitals (both $\mathrm{p}<0.01$ ) is shown in Table 1 and 2 . The adjusted OR for the type of labor in the two hospitals was nearly equal to 1 (in Leiden adjusted $O R ; 0.81$ and in Bandung adjusted OR; 1.20). The adjusted odd ratio for type of labor is difficult to interpret since it has been adjusted for the actual duration of labour. The fact that the crude odds ratio is greater than 1 while the adjusted odds ratio is smaller than 1 , is probably a consequence of confounding in the data.

\section{Fetal presentation}

Vertex presentation is associated with a much lower risk for cesarean delivery. As to be expected, fetal presentation strongly influences the obstetrician's decision to perform cesarean section. In Leiden the crude and adjusted OR's for breech and "other" groups were similar ( 5.79 vs 5.16 and 3.79 vs 3.89 , respectively) (Table 1). However, in Bandung, the crude and adjusted OR's were very extreme: the probability of undergoing a cesarean section was very low for the uterus group compared to the other presentations; the "other" group in this case included many presentations that had to be solved by cesarean section (brow/face, transverse and compound). In Bandung transverse presentation was the major factor resulting in a cesarean section.

\section{Prenatal visits}

The probabilities of cesarean section for women who did and did not attend a prenatal clinic did not differ greatly (adjusted $\mathrm{OR}=0.87, \mathrm{p}<0.03$ ). This means that women with more prenatal visits have a slightly lower chance of undergoing cesarean section in Bandung, provided the other risk factors involved are the identical.

\section{CONCLUSIONS}

In many aspects the factors which played an important role in the decision to perform a caesarean section were the same in Leiden and Bandung. There were however some differences. In Leiden multiple pregnancies were more often associated with an operative delivery than in Bandung. This was caused by the fact that in the Leiden data triplets and higher order births were over represented due to the practice of modem reproductive technologies. Haemorrhage was associated with a high risk for caesarean section in Bandung. This was probably caused by overdiagnosing of placenta previa. In Bandung a uterine scar was more often the reason for an operative delivery than in Leiden. The policy that after two previous caesarean section always a primary repeat caesarean combined with tubal ligation was performed, offers an explanation. The duration of labour in the Leiden data did not have a significant influence on the decision to perform a caesarean section. This is due to a more active ma nagement of labour which did not allow labour to last longer than 24 hours.

\section{REFERENCES}

1. Brand R, Keirse MJNC. Using logistic regression in perinatal epidemiology: An introduction for clinical researchers. Part I: basic concepts. Paediatric and Perinatal Epidemiology 1990; 4: 22-38.

2. Brand R. Using logistic regression in perinatal epidemiology: An introduction for clinical researchers. Part 2: the logistic regression equation. Paediatric and Perinatal Epidemiology 1990; 4: 221-35.

3. Marieskind HI.(editor). An evaluation of cesarean section in the United States. Final report submitted to Departmen of Health. Education and Welfare, June 1979 Washington DC. Washington DC: Department of Health, Education and Welfare, 1979 . 
4. Brassil MJ, Turner MJ, Egan DM et al. Obstetric outcome in first-time mother age 40 years and over. Eur J Obstet Gynecol Reprod Biol 1987; 25: 115-20.

5. Mor-Yosef S, Samueloff A, Modan B et al. Ranking the risk factors for cesarean section: Logistic regression analysis of a national wide study. Obstet Gynecol 1990; 75: 944-7.

6. Placek PJ, Taffel SM. Recent patters in cesarean delivery in the United States. Obstet Gynecol Clin North Am. 1988; 15: 607-27.

7. Read AW, Waddell VP, Prendiville WJ et al. Trends in cesarean section in Western Australia, 1980-1987. Med J Aust 1990; 153: 318-23.

8. Taffel SM, Placek PJ, Liss T. Trends in The United States cesarean section rate and reasons for the 1980-85 rise. Am J Public Heal th 1987; 77: 955-9.

9. Witter FR, Repke JT, Niebyl JR. The effect of maternal age on primary cesarean section rate. Int J Obstet Gynecol 1988; 27: 51- 5 .

10. Wirakusumah FF. A study of cesarean sections. A comparison of relevant factors and practices in Indonesia and the Netherlands [disertation]. Leiden, the Netherlands, University of Leiden, 1992.

11. Francome C, Huntingford PJ. Birth by cesarean section in the United State of America and in Britain. J Biol Soci Sci $1980 ; 12: 353$.
12. Gleicher N. The cesarean-section epidemic. Mt Sinai J Med $1986 ; 53: 563-5$.

13. Hurst M, Summey PS. Childbirth and social class: the case of cesarean delivery. Soc Scie Med 1984; 18: 621-31.

14. Anderson GM, Lomas J. Determinants of the increasing cesarean birth rate. $\mathrm{N}$ Engl J Med 1984; 311: 887-92.

15. Bottoms SF, Rosen MG, Sokol RJ. Current concepts. The increase in the cesarean birth rate. N Engl J Med 1980; 302: 559-63.

16. Newton ER, Higgins CS. Factors associated with hospitalspecific cesarean birth-rate. J Reprod Med 1989; 34: 407-11.

17. Rohra S, Bacchus MY. A review of cesarean section performed at the Georgetown Hospital, Guyana. West Indian Med J 1983; 32: 91- 6.

18. Cragin EG. Conservatism in Obstetrics: New York Med J 1916; 104: 1-3.

19. Evans MI, Fletcher JC, Zador IE et al. Selective firsttrimester termination in octuplet and quadruplet pregnancies; Clinical and ethical issues. Obstet Gynecol 1988; 71 : 289-96.

20. Schenker JG, Laufer N, Weinstein D et al. Quintuplet pregnancies. Eur J Obstet Gynec Reprod Biol 1980; 10: 257-68. 